\title{
A vital stain for studies of behaviour and ecology of the parasitic copepod Lernaeocera branchialis (Pennellidae)
}

\author{
Morten Anstensrud
}

Section of Marine Zoology and Chemistry, Biological Institute, University of Oslo, PO Box 1064, Blindern, N-0316 Oslo 3 , Norway

\begin{abstract}
To discriminate between individuals and groups of individuals, the vital stain neutral red was used to mark developmental stages of the parasitic copepod Lernaeocera branchialis (L.). The copepod has a marked ability to accumulate the stain, and the red colour of stained parasites lasts for ca 3 to $4 \mathrm{wk}$. Experiments demonstrate that exposure to $0.01 \mathrm{~g} \mathrm{l}^{-1}$ neutral red for $1 \mathrm{~h}$ does not reduce survival or interfere with mating and host-finding. The low toxicity and persistence of the stain suggest that it may be a useful tool in experimental work with copepods.
\end{abstract}

\section{INTRODUCTION}

A vital stain for behavioural studies of parasitic copepods requires that it does not reduce the survival rate, and that vital functions such as mating and hostfinding are not hampered. During current life-history studies of the parasitic copepod Lernaeocera branchialis, methods were sought whereby individuals could be marked and recognized.

The adult copepod infects different gadids in the North Atlantic, usually cod Gadus morhua L. or whiting Merlangius merlangus (L.) (Kabata 1979). The life cycle was described by Sproston (1942) and consists of 2 freeswimming nauplius stages and a copepodite stage followed by 2 parasitic stages (chalimus larvae), sessile on an intermediate host, usually flounder Platichthys flesus (L.). The mature mobile copepods copulate on the flatfish host after which the gravid female leaves the intermediate host. After infecting a final host, the female develops into the S-shaped egg-producing parasite.

Detailed studies of interactions between copepod individuals or groups of individuals, their behaviour and habitat utilization are difficult to perform without being able to follow single individuals or to distinguish between different groups of copepods. Experiments with different stains indicated that the vital stain neutral red could be a useful marker; the copepods attained a bright red colour and seemed to behave normally after staining.
The aim of this study was to examine the effects of neutral red on the survival and behaviour of Lernaeocera branchialis and to investigate its usefulness in experimental studies of this copepod.

\section{MATERIAL AND METHODS}

Egg sacs of Lernaeocera branchialis (L.) were hatched in the laboratory and the larvae raised in aquaria using the technique described by Schram \& Anstensrud (1985). Flounder were used as host animals and all experiments were performed at 10 to $12{ }^{\circ} \mathrm{C}$ and 30 to $31 \%$ Salinity.

Initial experiments with aqueous solutions of Janus green B, Methyl green, Rose bengal and Acridine orange were not successful either due to low permeability of the stains or because the colour of the stained copepods disappeared within a week. In later experiments only neutral red was used.

A stock solution of neutral red (3-amino-7-dimethylamino-2-methylphenazine hydrochloride, molecular weight 288.8) was prepared by dissolving $0.1 \mathrm{~g}$ of the stain in $1 \mathrm{l}$ of seawater 1 to $2 \mathrm{~h}$ before the start of the experiments.

To study the exposure time required for Lernaeocera branchialis males to attain a noticeable red colour, 20 free-swimming males were exposed to each of 3 concentrations of neutral red; $0.01,0.001$ and $0.0001 \mathrm{~g} \mathrm{l}^{-1}$. Twenty males were exposed to the stock solution $(0.1 \mathrm{~g}$ 
$\mathrm{1}^{-1}$ ) for $30 \mathrm{~min}$ and were used as controls. The time required for all 20 parasites in each group to obtain the same degree of staining was recorded by visually comparing the 3 experimental groups to the control.

In addition, 80 males on a flounder host were exposed to $0.01 \mathrm{~g} \mathrm{l}^{-1}$ neutral red for $1 \mathrm{~h}$ and later observed twice a week to study the persistence of the red colour.

In an attempt to examine the effect of ecdysis on the coloration of stained Lernaeocera branchialis, one flounder carrying 300 newly settled copepodites was exposed to $0.01 \mathrm{~g} \mathrm{l}^{-1}$ neutral red for $1 \mathrm{~h}$ and then transferred to fresh seawater. The coloration of the larvae through 5 moults, their mating success after maturity and the development of stained females on the final host were studied.

Free swimming adults of Lernaeocera branchialis were obtained by removing secondary gill lamellae with mature males or females from the flounder. The gill tips were placed in $200 \mathrm{ml}$ glass beakers containing seawater; the parasites left their lamellae within 1 to $2 \mathrm{~h}$.

The survival of unstained and stained $\left(0.01 \mathrm{~g} \mathrm{l}^{-1}\right.$ neutral red solution for $1 \mathrm{~h}$ ) free-swimming males was recorded in $30 \times 25 \times 5 \mathrm{~cm}$ plastic jars containing filtered seawater. Unstained and stained males were also exposed to flounder in $150 \mathrm{l}$ aquaria, and the number of males located on the host was recorded after $22 \mathrm{~h}$. The same type of experiment was performed with unstained and stained copepodites and gravid females. The latter were exposed to cod.

Free-swimming Lernaeocera branchialis males were exposed to each of 4 concentrations of neutral red: 0.5 , $0.05,0.005$ and $0.0005 \mathrm{gl} \mathrm{l}^{-1}$. The males were kept in $300 \mathrm{ml}$ glass beakers, and their survival during prolonged exposure to neutral red was recorded.

\section{RESULTS}

\section{Coloration}

As shown in Fig. 1, males of Lernaeocera branchialis have a marked ability to accumulate neutral red. Even in solutions containing $0.0001 \mathrm{~g} \mathrm{l}^{-1}$ neutral red, the copepods reached approximately the same coloration after $19 \mathrm{~h}$ as those exposed to the stock solution $10.1 \mathrm{~g}$ $\mathrm{l}^{-1}$ ) for $30 \mathrm{~min}$. Usually, exposure to neutral red concentrations between 0.005 and $0.01 \mathrm{~g} \mathrm{l}^{-1}$ for 1 to $2 \mathrm{~h}$ will give the copepods a bright red colour. These stained individuals are recognizable with the naked eye even in the gill cavity of a live flounder.

Stained males on the flatfish host can be recognized for 3 to $4 \mathrm{wk}$, depending on the degree of staining. Females remain stained at least until metamorphosis, when the colour of neutral red is overshadowed by the natural red colour of the egg-producing parasite.
Both larval exuvia and dissected mature individuals were examined, and it appeared that all parts of both male and female Lernaeocera branchialis except the integument are stained by neutral red. However, the stained males produce normal, greyish-white spermatophores.

\section{Survival}

The survival frequencies presented in Fig. 2 were arcsine transformed, and regression analysis revealed a highly significant linear relation between arcsine survival and the time in each of the 6 experiments ( $F$ varied between 36.32 and 136.43, $p<0.0025$; $r$ varied between 0.94 and $0.98, p<0.001$ ). An analysis of covariance applied on these linear regressions showed that exposure to a moderate concentration of neutral red $\left(0.01 \mathrm{~g} \mathrm{l}^{-1}\right)$ for $1 \mathrm{~h}$ has no significant effect on the

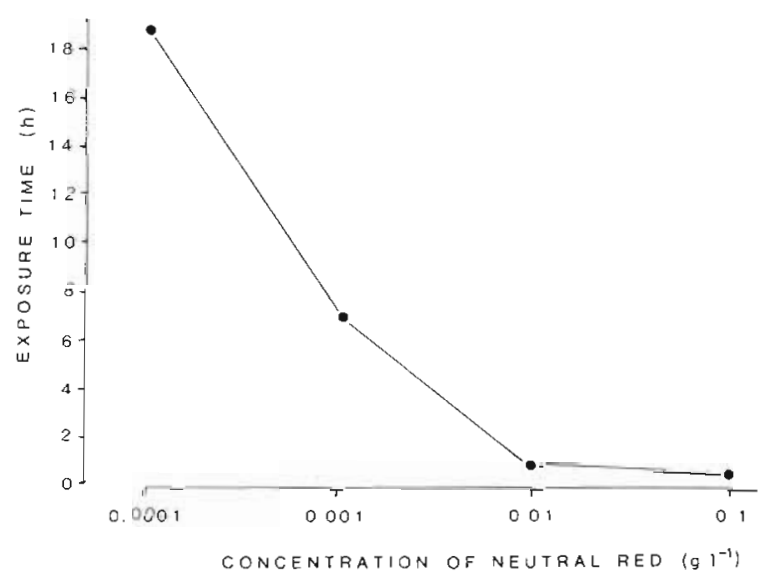

Fig. 1. Lernaeocera branchialis. Exposure time needed to obtain the same degree of staining of 20 males in 4 concentrations of neutral red

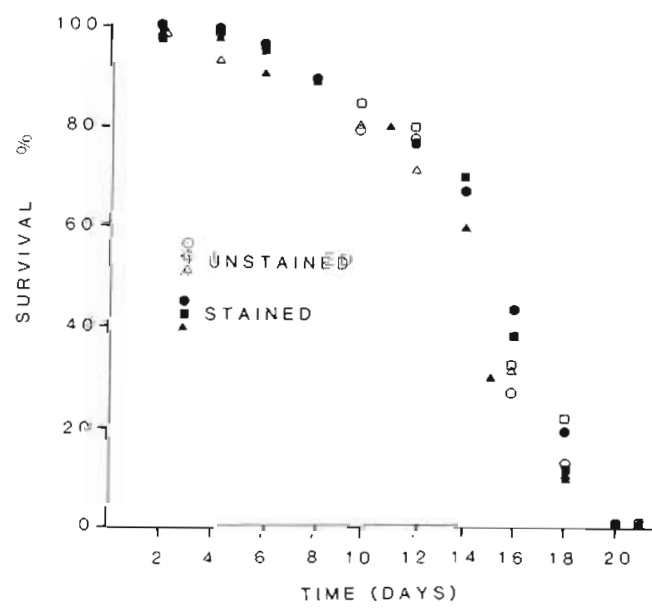

Fig. 2. Lernaeocera branchialis. Survival of unstained $(n=70)$ and stained $(n=85)\left(0.01 \mathrm{~g} \mathrm{t}^{-1}\right.$ neutral red solution for $1 \mathrm{~h}$ ) free-swimming males in 3 replicate experiments 
survival of Lernaeocera branchialis males separated from the flatfish host $\left(F_{\text {elevation }}=0.63, F_{\text {slope }}=0.03, p>\right.$ $0.25)$. About $50 \%$ of both stained and unstained specimens survived for ca $15 \mathrm{~d}$, and no males survived longer than 20 to $21 \mathrm{~d}$.

Both the persistence of the red colour of stained Lernaeocera branchialis and their ability to accumulate neutral red show that the rate of stain absorption is faster than the rate of release. During prolonged exposure to a stain solution, the concentration of neutral red within the copepods increases and they die (Fig. 3). Male L. branchialis kept in $0.5 \mathrm{~g} \mathrm{l}^{-1}$ neutral red solution developed a very dark red colour and died within $4 \mathrm{~h}$, whereas those in $0.0005 \mathrm{~g} \mathrm{I}^{-1}$ solutions survived for 6 to $10 \mathrm{~d}$. During this time they developed the same dark red colour before they died. The control groups survived for 7 to $14 \mathrm{~d}$.

\section{Vital functions}

During larval development, the red colour of stained Lernaeocera branchialis is maintained with a decrease in the intensity. This is probably due both to growth, which results in an increase in the body volume of the copepods, and to normal fading of stained copepods.

A sample of 50 stained Lernaeocera branchialis pairs was observed during mating, and all males successfully transferred spermatophores. All the stained females located a final host (cod), and developed normally into the W-stage (Sproston \& Hartley 1941)

Exposure to $0.01 \mathrm{~g} \mathrm{l}^{-1}$ neutral red solution for $1 \mathrm{~h}$ does not seem to reduce the ability of infective Lernaeocera branchialis stages to locate and recognize a host (Fig. 4). At the end of each experiment (after $22 \mathrm{~h}$ ), between 45 and $75 \%$ of the test copepods were located on the host fish, all in the gill cavity. According to the Friedman test (Conover 1980), there were no significant differences between stained and unstained males, females and copepodites $(p>0.25)$.

\section{DISCUSSION}

Neutral red is a weak base (Harms 1965) and will accumulate in acid cellular environments. The model of lysosomal pH maintenance and uptake of weak bases described by Poole \& Ohkuma (1981) could explain the accumulation and persistence of the stain in Lernaeocera branchialis: the lysosomal membrane is much less permeable to the protonated form of a weak base than

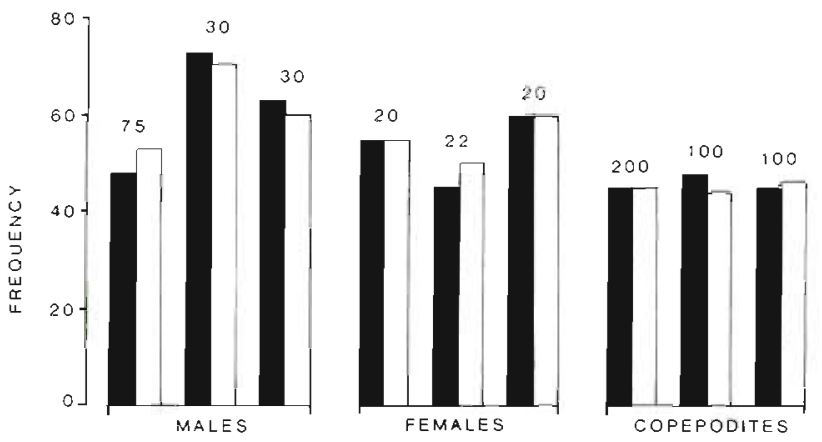

Fig. 4. Lernaeocera branchialis. Frequency of infection of a host within 22 h of exposure for unstained (open columns) and stained $\left(0.01 \mathrm{~g} \mathrm{l}^{-1}\right.$ neutral red solution for $\left.1 \mathrm{~h}\right)$ (black columns) free-swimming males, females and copepodites. Equal numbers of stained and unstained individuals were used in each experiment. Number of stained (and thereby unstained) individuals in each experiment is shown over columns
Fig. 3. Lernaeocera branchialis. Mean survival and standard errors of 3 replicate experiments with free-swimming males during constant exposure to 4 concentrations of neutral red. Twenty males were used in each replicate

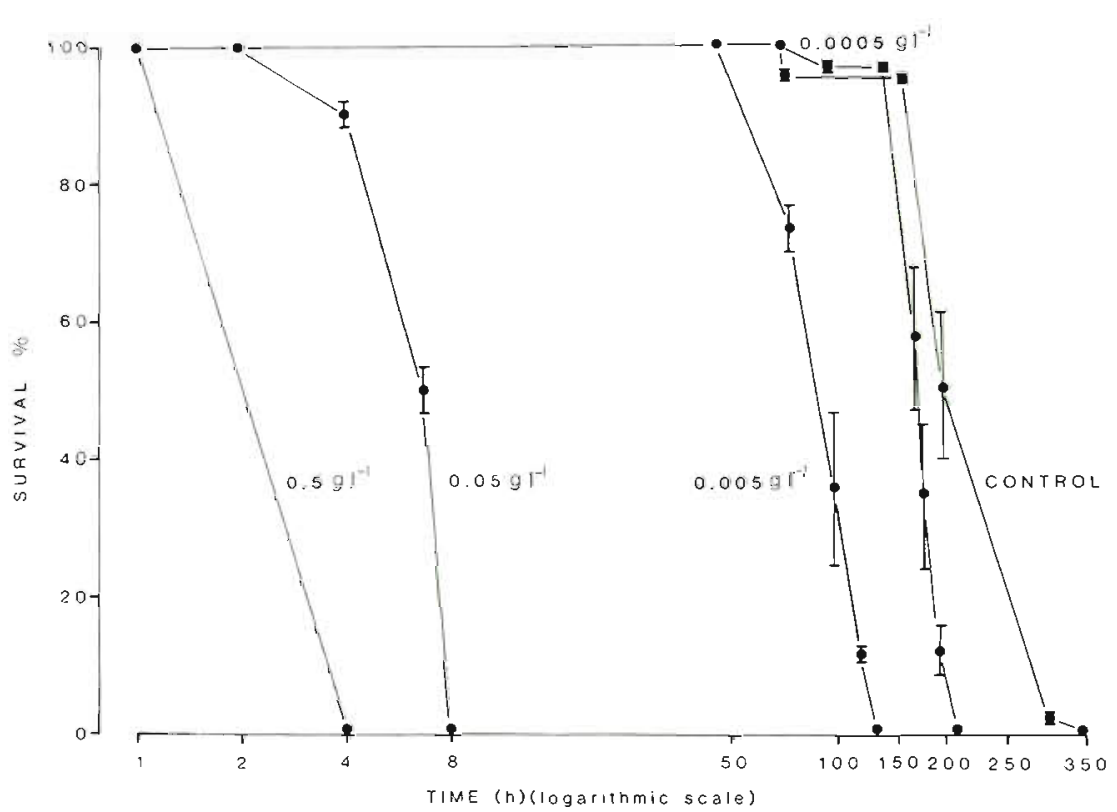


it is to the free base. The free base, in this case neutral red, diffuses rapidly across the plasma and lysosomal membranes and because of the acidity inside the lysosome, the base is trapped there by protonation. However, the presence of neutral red inside the lysosymes has not been verified.

Developmental stages of Lernaeocera branchialis stained with neutral red are easy to recognize for several weeks, and unless the specimens are overexposed, this stain seems to have little or no effect on the survival and behaviour of the copepod. Further testing of different stains will probably demonstrate that copepods can be marked with other colours as well, and Meinhardt (1976) successfully used the green food dye No. 5/ 047451 (E 102 + E 132) on earthworms. This dye may probably also be used on copepods.

Neutral red may also be a useful tool in studies of the ecology and behaviour of other copepod species, e.g. studies of intraspecific interactions or communication and transfer of parasitic copepods between host individuals and different microhabitats. The concentration and exposure time needed will vary between different stains and probably between different copepod species due to differences in the integument and thus in permeability to the stain.

This article was submitted to the editor
Acknowledgements. I am greatful to Dr K. B. Doving, Professor M. Christiansen and Professor J. S. Gray for critically reading the manuscript and $A$. J. Coulthard for correcting the English.

\section{LITERATURE CITED}

Conover, W J. (1980). Practical nonparametric statistics, 2nd edn. John Wiley \& Sons, New York

Harms, N. G. (1965). Handbuch der Farbstoffe für die Mikroskopie. Staufen Verlag, Lintfort

Kabata, Z. (1979). Parasitic copepods of British fishes, Ray Soc., London

Meinhardt, U. (1976). Dauerhafte Markierung von Regenwürmern durch ihre Lebenfärbung. Nachrichtenbl. Dtsch. Pflanzenschutzdienstes (Braunschweig) 28: 84-86

Poole, B., Ohkuma, S. (1981). Effect of weak bases on the intra lysosomal $\mathrm{pH}$ in mouse peritonal macrophages. J. Cell Biol. 90: 665-669

Schram, T A., Anstensrud, M. (1985). Lernaeenicus sprattae (Sowerby) in the Oslofjord plankton and some laboratory experiments with the nauplius and copepodid (Copepoda, Pennellidae). Sarsia 70: 127-134

Sproston, N. G. (1942). The developmental stages of Lernaeocera branchialis (Linn.). J. mar. biol. Ass. U. K. 25: $441-466$

Sproston, N. G., Hartley, P. H. T. (1941). The ecology of some parasitic copepods of gadoids and other fishes. J. mar. biol. Ass. U. K. 25: 361-392

Manuscript first received: June 28, 1988

Revised version accepted: January 12, 1989 